\title{
The Profile of Students Activities; Before, During and After Learning
}

\author{
Fikriyanda ${ }^{1}$, Daharnis ${ }^{1}$, Verlanda Yuca ${ }^{1}$ \\ ${ }^{1}$ Universitas Negeri Padang \\ *Corresponding author, e-mail: fikriyanda007@gmail.com
}

\begin{abstract}
Learning activities are a learning effort by students in physical, mental, intellectual, and emotional aspects from the to hard observed activities that happened inside or outside the classroom. This study describes students learning activities that will impact on student learning outcomes. The method used is descriptive-analysis with a 167 students sample that using proportional random sampling technique, used a questionnaire. The instrument used is a questionnaire. The result of the research is it includes the students learning activities in Junior High school in the medium category which comprises learning activities before learning in school, learning during school, and after learning in school. The implications of this research can be a reference and input for Counselor to improve students learning activities at 19 Junior High school in Bandung.
\end{abstract}

Keywords: learning activities, learning process, students profile

How to Cite: Fikriyanda, F., Daharnis, D., Yuca, V. (2019). The Profile of Students Activities; Before, During and After Learning. Int ernational Journal of Research in Counseling and Education, 3 (1): pp. 49-54. DOI: $10.24036 / 0077 z a 0002$

\section{Introduction}

Learning is an activity that aims to get behavioral changes. Such behavioral changes include changes in understanding, knowledge, attitudes, skills, and habits (Uno, 2008). It relates experience in the learning process to the interaction between individuals and their environment (Sardiman, 2004).

The whole process of development requires learning, and every child develops through learning activities to support its full development (Syah, 2011) and the core of learning is learning activities undertaken by students (Hanafiah \& Suhana, 2009; Hasanah, 2010). In the world of education, learning activities are activities undertaken by students; and the students do it in the learning, either during the learning process inside and outside the classroom (Alizamar, 2016; Daharnis \& Ardi, 2016). Learning activities have a variety of forms ranging from observed physical activity to psychological activities difficult to observe (Dimyati, 2006; Sardiman, 2004) oriented to changes in his behavior with the right and true, both related to aspects of cognitive, affective, and psychomotor (Hamalik, n.d.; Hanafiah \& Suhana, 2009; Hasanah, 2010). Learning activity it comprises learning activities before, during, and after learning in educational institutions (Daharnis, Erlamsyah, Ifdil, Ardi, \& Hariko, 2014b; Millis, 2016).

Good learning activities will get good learning outcomes as well (Daharnis \& Ardi, 2016; Nirwana, 2003), but judging from the circumstances there are still many students who have not noticed how important the learning activities. Besides learning outcomes, learning activities are at the core of the meaning of education in a broad sense, the development of learners of learners that can educate the life of the nation and can realize the ideals of the government in Indonesia that is the generation of gold in 2045 (Suranata et al., 2018) that can compete in the global area (Presiden Republik Indonesia, 2003).

The ideals of government to achieve it all and associated with learning activities one of the core of the meaning of education in the broad sense can still be said has not been achieved. The results of Indonesian learning activities seen from the acquisition of the value of National Examination (Ujian Nasional) they can still say every year to be less satisfactory. The statistic data released by the Ministry of Education and Culture 
shows that the average value of the National Examination for Junior High School level has always decreased from 2016 to 2018. Under such circumstances, research needs to be done to know one factor which affects the results of the student's National Exmaination student learning activities.

This research focuses on students of class VIII in Junior Highschool 19 Bandung academic year 2016/2017. The purpose of the study was conducted in Junior Highschool 19 Bandung because this school accredited A with the average value of the National Examination in 2015 to get the 43rd position of 55 junior high school in Bandung and in 2016 occupies the 34th position. Although the position of Junior Highschool 19 Bandung increased in 2016, but overall the average score of subjects from the National Examination has decreased except the average science subjects that rose by 3.92 (9.34\%).

Referring to data reduction of learning outcomes from year to year and as an effort to determine the factors that affect the results of the National Examination, then this study seeks to describe student learning activities. The results expected to be a reference and effort from various parties to cope with low learning outcomes by not only focusing on the upgrading of teachers; development of media, materials, and learning strategies; improvement of facilities; development of evaluation tools and strategies; and disciplinary enforcement but also to student learning activities are at the core of the broader education ("Gambaran Kegiatan Belajar Siswa Sumatera Barat," 2014).

\section{Method}

This research uses a quantitative approach of descriptive-analytic method conducted in 2017 at Junior High school 19 Bandung. The study population is all students of class VIII Junior High school 19 Bandung with a sample of 167 students selected using proportional random sampling technique. The instrument used was a Likert model scale questionnaire with modification from the Daharnis Learning Activities Scale (DLAS) instrument whose aspects consisted of activities before, during, and after learning in school (Daharnis, Erlamsyah, Ifdil, Ardi, \& Hariko, 2014a). Reliability of the instrument used is equal to 0.838 (Alpha Cronbach). Statistical data analysis descriptive (mean percentage of achievement level based on comparison with an ideal score, SD, and frequency).

\section{Results and Discussion}

The results of research on the students of class VIII SMP Negeri 19 bandung got an average value of 176.11 (level of achievement 66.7\%), standard deviation of 19.173 with the lowest score of 125 and the highest score of 241. It divides category of student learning activities into in the three categories of high, medium and low. The calculation uses the level categorization (Azwar, 2015) with the results presented in Table 1.

Table 1.

Condition of Student Learning Activities

\begin{tabular}{|c|c|c|c|}
\hline Category & Score & Frequency & Percentage \\
\hline High & $198-264$ & 19 & $11.4 \%$ \\
\hline Medium & $133-197$ & 146 & $87.4 \%$ \\
\hline Low & $66-132$ & 2 & $1.2 \%$ \\
\hline
\end{tabular}

The results of data processing of student activities of class VIII Junior high school 19 Bandung in general is in the medium category that is 146 students (87.4\%). The results of students' research activities categorized being in class VIII Junior Highs school 19 Bandung slightly different from the results of research conducted on the entire students in West Sumatra was categorized high, although results are not satisfactory ("Gambaran Kegiatan Belajar Siswa Sumatera Barat," 2014). Such circumstances may occur due to differences in the cultural background between Sunda (West Java) and Minang (West Sumatra); and factors of the number of samples and research instruments used so that require further research.

Recapitulation aspects of pre-learning activities, during learning, after school learning, and overall learning activities are presented in Table 2. 
Table 2.

Recapitulation of Research Results by Frequency, Percentage, and Score

\begin{tabular}{|c|c|c|c|c|c|c|c|c|c|c|}
\hline \multirow{2}{*}{ No } & \multirow{2}{*}{ Aspect } & \multicolumn{2}{|c|}{ High } & \multicolumn{2}{|c|}{ Medium } & \multicolumn{2}{|c|}{ Low } & \multirow{2}{*}{ Mean } & \multirow{2}{*}{ \% } & Category \\
\cline { 3 - 9 } & & f & $\%$ & f & $\%$ & f & $\%$ & & Achievements & \\
\hline 2 & $\begin{array}{c}\text { Before } \\
\text { learning }\end{array}$ & 17 & $10.2 \%$ & 140 & $83.8 \%$ & 10 & $6 \%$ & 51.78 & $64,72 \%$ & Medium \\
\hline 3 & $\begin{array}{c}\text { During } \\
\text { learning }\end{array}$ & 17 & $10.2 \%$ & 149 & $89.2 \%$ & 1 & $0.6 \%$ & 74.83 & $66.81 \%$ & Medium \\
\hline 4 & $\begin{array}{c}\text { After } \\
\text { Learning } \\
\text { Activity }\end{array}$ & 43 & $25.7 \%$ & 119 & $71.3 \%$ & 5 & $3 \%$ & 49.5 & $68.75 \%$ & Medium \\
\hline
\end{tabular}

Table 2 shows activities prior to learning, while learning and after schooling is in the medium category. However, in the aspect before the learning in the school and after the learning in the school, it was found that some students were in the low category and only 1 students were categorized as low on aspects during the lesson. This means there are some students whose learning activities are carried out only in the learning activities at school and rarely take time off at home; because learning activities before and after learning are done outside of school.

With regard to the utilization of study time, there are some similarities with other researchers and mutually supportive conclusions. Research in one of the high schools in Sleman about the utilization of study time outside of school hours that is before the learning in school and after learning in school is in the medium category (Kurnianingtyas \& Sumarsih, 2016). A survey of 20,000 American students also found that $40 \%$ of students attend school lessons, $90 \%$ of students have cheated homework, and $66 \%$ of students have cheated on tests or tests (Woodfolk, 2008).

The results also found there were some items that scored relatively low student learning activity from each aspect of the result as seen in table 3.

Table 3

The Type of Learning Activity Getting the Lowest Score

\begin{tabular}{|c|c|c|c|c|}
\hline No & Aspect & Item statement & Score & $\begin{array}{c}\% \\
\text { achievement } \\
\text { s }\end{array}$ \\
\hline \multirow{2}{*}{1.} & \multirow{2}{*}{ Before learning } & $\begin{array}{l}\text { I. I prepare questions from unintelligible subject } \\
\text { matter to ask the teacher at school }\end{array}$ & 298 & $44.61 \%$ \\
\hline & & $\begin{array}{l}\text { 2. I make my own questions about the subject } \\
\text { matter I have learned }\end{array}$ & 285 & $42.66 \%$ \\
\hline \multirow{4}{*}{2.} & \multirow{4}{*}{$\begin{array}{l}\text { During school } \\
\text { learning }\end{array}$} & $\begin{array}{l}\text { 1. If given the opportunity, I try to occupy the } \\
\text { front seat to learn }\end{array}$ & 373 & $55.83 \%$ \\
\hline & & $\begin{array}{l}\text { 2. I record the essence of the lesson without } \\
\text { being asked by the teacher }\end{array}$ & 377 & $56.43 \%$ \\
\hline & & $\begin{array}{l}\text { 3. I created my own summary to easily } \\
\text { understand the subject matter }\end{array}$ & 384 & $57.48 \%$ \\
\hline & & $\begin{array}{l}\text { 4. I asked the teacher when I did not understand } \\
\text { the subject matter }\end{array}$ & 377 & $56.43 \%$ \\
\hline
\end{tabular}




\begin{tabular}{|l|c|c|c|c|}
\hline No & Aspect & Item statement & Score & $\begin{array}{c}\% \\
\text { achievement } \\
\text { s }\end{array}$ \\
\hline 3. & $\begin{array}{c}\text { After the } \\
\text { Learning } \\
\text { Process at } \\
\text { school }\end{array}$ & $1 . \quad$ I repeating the lessons learned before, at home & 354 & $52.99 \%$ \\
\cline { 2 - 5 } & $\begin{array}{l}\text { I do exercises to learn the subject matter even } \\
\text { though it is not assigned by the teacher }\end{array}$ & 339 & $50.74 \%$ \\
\hline
\end{tabular}

Based Table 3 above, i t can be seen that learning is not a single activity, but a series of activities that are integrated, related and support each other (Prayitno, 2007). With the lack of students of Junior high school 19 Bandung preparing questions that are not understood before the lesson, it impacts the activities while learning in schools that do not ask the teacher. Lack of questioning activities during school learning makes the students focus only on listening to the material presented by the teacher and the results of the study also found that many students did not record the material presented by the teacher. Activities that do not record the subject matter will hamper the learning process of students in the future because it can forget what is conveyed by teachers who impact on learning outcomes when the exam. Meanwhile, the learning activities after the learning process in school is rarely done by students is to repeat the subject matter that has been obtained after the learning process at school, which is usually done at night or after school that affects the memory of students. By repeating the lesson material that has been submitted and doing the exercises, students become no trouble in facing impromptu tests so as not to stress facing it.

Various factors will create good learning activities, one of which is the supportive school social environment with the creation of a good school social environment and the creation of harmonious relationships between fellow students and with teachers will support learning activities (Alizamar, 2016) (Alizamar, 2019; Daharnis \& Ardi, 2016; Slameto, 2010; Syah, 2011) (Fikriyanda, 2017). Besides the state of the school social environment, learning motivation also contributes to improve student learning activities that improve life skills and student learning outcomes (Kiswoyowati, 2011). Learning activities also contributed to the achievement of learning under the results of research conducted on the seventh grade students of Junior Highschool 16 Surakarta so students should pay attention to their learning activities to get satisfactory results (Khomsatun, 2006).

Roles subject teachers can provide that to help improve learning activities by using varied learning methods and able to manage the class to support and encourage active students in the learning process and not passive because of the method of learning that emphasizes student activeness has a greater positive effect than student learning with a passive approach to learning (Castro et al., 2009; Eison, 2010; Santrock, 2011; Slavin, 2011). Besides the role of subject teachers, school counselor can provide individual or group services (Nasional, 2008; Winkel \& Hastuti, 2010; Yuca, Ahmad, \& Ardi, 2017). It can provide one approach and technique of individual counseling services using behavioristic approaches and techniques (Daharnis \& Ardi, 2016). School counselor can also provide information services and content mastery to students' learning abilities and selecting factors that influence student learning activities to become guidance counseling service programs.

Good student relationships also affect the spirit and learning activities of students (Syah, 2011). The relationship and poor quality of friendship between students or tend to be rejected by peers is likely to cause dropout students. Even students who tend to be rejected, have many problems during adulthood (Juniyarti, Prayitno, \& Marjohan, 2018; Woodfolk, 2008).

Parents also play an important role in the learning process because two aspects of the learning activities are before and after learning at school occur at home and learning institutions, thus demanding the need for parental attention (Ardi et al., 2018; Hasgimianti, Nirwana, \& Daharnis, 2017). By taking part and facilitating diverse learning experiences and activities outside the school, parents can help improve student learning activities to improve the quality and outcomes of children (Emerson, Fear, Fox, \& Sanders, 2012)(Daharnis \& Ardi, 2016).

\section{Conclusion}

Learning activities are important activities that must be by students because without the activity, the learning process is not possible. However, seen from the results of research is still a lot of students of class VIII Junior Highschool 19 Bandung that carry out the learning activities as it should and categorize is. Such 
conditions require the attention of parents, communities and schools; school counselor to provide services that can develop and enhance learning activities.

Other efforts can be made by conducting research on a larger population as a need assessment to produce a comprehensive guidance counseling service program. Guidance counseling program developed is expected to increase the average value of Ujian Nasional, which from 2016 to 2018 always decreased to achieve the goals and educational objectives that produce humans quality and able to compete in the global area.

\section{References}

Alizamar, A. (2016). Teori Belajar dan Pembelajaran. Yogyakarta: Media Akademi.

Alizamar, A. (2019). Pengembangan Karakter-Cerdas Mahasiswa melalui Infusi dalam Pembelajaran.

Ardi, Z., Sukmawati, I., Ifdil, I., Afdal, A., Rangka, I. B., \& Suranata, K. (2018). Exploring the acceptability of internet-based mental health mobile app services using network psychometrics analysis. In Journal of Physics: Conference Series (Vol. 1114, p. 12106). IOP Publishing.

Azwar, S. (2015). Penyusunan Skala Psikologi. Ed. 2, Cet. VII. Yogyakata: Pustaka Pelajar.

Castro, R. M., Kalish, C., Nowak, R., Qian, R., Rogers, T., \& Zhu, J. (2009). Human active learning. In Advances in neural information processing systems (pp. 241 248).

Daharnis, D., \& Ardi, Z. (2016). THE COMPATIBILITY STUDENT CHOICE OF UNIVERSITY MAJORING; A PRELIMINARY STUDIES. GUIDENA: Journal of Guidance and Counseling, Psychology, and Education, G(1), 101109.

Daharnis, D., Erlamsyah, E., Ifdil, I., Ardi, Z., \& Hariko, R. (2014a). Daharnis Learning Activities Scale. Padang.

Daharnis, Erlamsyah, Ifdil, Ardi, Z., \& Hariko, R. (2014b). Gambaran Kegiatan Belajar Siswa Sumatera Barat. In Seminar Internasional Bimbingan dan Konseling(Vol. 1, pp. 1 9). https://doi.org/10.1017/CBO9781107415324.004

Dimyati, M. (2006). Belajar dan pembelajaran. Jakarta: Rineka Cipta.

Eison, J. (2010). Using active learning instructional strategies to create excitement and enhance learning. Jurnal Pendidikantentang Strategi Pembelajaran Aktif (Active Learning) Books, 2(1), 110.

Emerson, L., Fear, J., Fox, S., \& Sanders, E. (2012). Parental engagement in learning and schooling: Lessons from research. A Report by the Australian Research Alliance for Children and Youth (ARACY) for the Family School and Community Partnerships Bureau: Canberra.

Gambaran Kegiatan Belajar Siswa Sumatera Barat. (2014).

Hamalik, O. (n.d.)._. 2011. Proses Belajar Mengajar. Jakarta: PT Bumi Aksara.

Hanafiah, N., \& Suhana, C. (2009). Konsep strategi pembelajaran. Bandung: Refika Aditama.

Hasanah, H. (2010). Hubungan antara adversity quotient dengan prestasi belajar siswa SMUN 102 Jakarta Timur.

Hasgimianti, H., Nirwana, H., \& Daharnis, D. (2017). PERHATIAN ORANGTUA DAN MOTIVASI BELAJAR SISWA YANG BERLATAR BELAKANG MELAYU DAN JAWA. INSIGHT: Jurnal Bimbingan Dan Konseling, 6(2), 130143.

Juniyarti, M. E., Prayitno, P., \& Marjohan, M. (2018). Content Mastery Service: A Help In Related Consulting Problems Student Learning Activities. International Journal of Research in Counseling and Education, $1(3), 4346$.

Khomsatun, S. (2006). Pengaruh pembelajaran di luar kelas terhadap prestasi belajar siswa ditinjau dari antusiasme belajar siswa pada siswa SMP Tahun ajaran 2004/2005. Universitas Sebelas Maret.

Kiswoyowati, A. (2011). Pengaruh motivasi belajar dan kegiatan belajar siswa terhadap kecakapan hidup siswa. Portal Jurnal Universitas Pendidikan Indonesia, 2(1), 1216.

Kurnianingtyas, D., \& Sumarsih, S. (2016). PENGARUH PEMANFAATAN WAKTU BELAJAR SISWA DI LUAR JAM PELAJARAN DAN PERHATIAN ORANG TUA TERHADAP PRESTASI BELAJAR AKUNTANSI. Kajian Pendidikan Akuntansi Indonesia, 5(5).

Millis, B. J. (2016). Using Metacognition to Promote Learning. IDEA Paper\# 63. IDEA Center, Inc. 
Nasional, D. P. (2008). Penataan pendidikan profesional konselor dan layanan bimbingan dan konseling dalam jalur pendidikan formal. Jakarta: Direktorat Jenderal Pendidikan Tinggi.

Nirwana, H. (2003). Hubungan Tingkat Aspirasi dan Persepsi tentang Belajar dengan Hasil Belajar Matematika Siswa Sekolah Menengah Umum yang Berlatar Belakang Budaya Minangkabau dan Batak. Disertasi Tidak Diterbitkan. Malang: Program Studi Psikologi Pendidikan Pascasarjana UM.

Prayitno. (2007). Pengembangan Potensi Mahasiswa. Padang: UNP Press.

Presiden Republik Indonesia. (2003). Undang-undang Republik Indonesia nomor 20 tahun 2003 tentang sistem pendidikan nasional. Jakarta: Pemerintah Republik Indonesia.

Santrock, J. W. (2011). Psikologi pendidikan edisi ke 2 (terjemahan Tri Wibowo). New York, NY: McGraw-Hill Companies.(Buku asli diterbitkan tahun 2004).

Sardiman, A. M. (2004). Interaksi \& motivasi belajar mengajar. Rajagrafindo Persada (Rajawali Pers).

Slameto, B. (2010). Faktor-faktor yang mempengaruhi. Jakarta: Rineka Cipta.

Slavin, R. E. (2011). Psikologi pendidikan teori dan praktik. Jakarta: Indeks.

Suranata, K., Rangka, I. B., Ifdil, I., Ardi, Z., Susiani, K., Prasetyaningtyas, W. E., $\quad$ Rahim, R. (2018). Diagnosis of students zone proximal development on math design instruction: A Rasch analysis. In 2018 Workshop on Multidisciplinary and Its Applications: Applied Mathematics, Computer Science, Information Systems, and Information Technology, WMA-Mathcomtech 2018(Vol. 1114). Institute of Physics Publishing. https://doi.org/10.1088/1742-6596/1114/1/012034

Syah, M. (2011). Psikologi Belajar (Cet. XI). Jakarta: PT Raja Grafindo Persada.

Uno, H. B. (2008). Teori motivasi dan pengukurannya. Jakarta: Bumi Aksara.

Winkel, W. S., \& Hastuti, S. (2010). Bimbingan Konseling di Institusi Pendidikan Edisi Revisi. Jakarta: Grasindo.

Woodfolk, A. (2008). Educational psychology: Active learning edition. Boston: Allyn \& Bacon.

Yuca, V., Ahmad, R., \& Ardi, Z. (2017). The Importance of Infrastructure Facilities in Counseling Services. In 9th International Conference for Science Educators and Teachers (ICSET 2017). Atlantis Press. 